\title{
THE PERFORMANCE OF SOUTH AFRICAN SHARED SERVICES
}

\author{
R.R. Ramphal ${ }^{1}$ \\ Department of Business Management \\ University of South Africa, South Africa \\ ramphrr@unisa.ac.za
}

\begin{abstract}
Many South African companies are adopting the shared services methodology because this structure has led to lower operating costs, greater business efficiency, and improved internal service quality in international companies. Part of a doctoral study on shared services in South African companies shows that their business unit managers have not yet experienced positive rewards from their shared services. This article reports on this study, and suggests a larger-scale research project to validate these findings and to investigate the reasons for the poor performance.
\end{abstract}

\section{OPSOMMING}

Baie Suid-Afrikaanse maatskappye maak toenemend gebruik van die 'shared services'metodologie omdat die struktuur daarvan kan lei tot ' $n$ afname in operasionele koste, verbeterde besigheidseffektiwiteit, en verhoogde diensgehalte in internasionale maatskappye. 'n Doktorale studie oor 'shared services' in Suid-Afrikaanse maatskappye wys daarop dat individuele besigheidseenheidsbestuurders nie ' $n$ positiewe belewenis het met 'shared services' nie. Hierdie artikel verwys na dié studie, en stel voor dat 'n meer omvangryke navorsingsprojek onderneem word om die bevindinge te staaf, sowel as om die redes vir swak prestasie te ondersoek.

\footnotetext{
${ }^{1}$ The author completed a doctoral study in organisational leadership at the Business School of the Tshwane University of Technology.
} 


\section{INTRODUCTION}

Many South African organisations have adopted the 'shared services' methodology. This follows the international trend of using this approach to solve organisational problems and improve organisational performance (Ulrich [14]).

The literature shows that the benefits of using the shared services structure include reduced operating costs, correct deployment of employees for certain core functions within the organisations concerned, increased internal service quality, and greater business efficiencies (Redman et al. [8]; Schulman et al. [11]). However, part of the doctoral study by this author shows that some South African organisations that have implemented shared services structures are not yet achieving these benefits. The results show that they are performing below the rank of 4 (on a Likert scale from 1 to 7 ).

This article discusses the characteristics and current performance of the shared services of South African organisations. Reasons for the poor performance are also suggested.

\section{SHARED SERVICES}

The shared services structure has spread quite rapidly since the late 1990s, and has become a popular organisational change approach for managers who are dissatisfied with their current organisational performance (Ulrich [14]). Various authors (Ulrich [14]; Mercer [7]; Grant et al. [4]; Webster [15]; Bergeron [1]; Schulman et al. [11]) have defined 'shared services'. All define the shared services approach as the collection and concentration of duplicated non-core and non-value-adding activities from the various business units of an organisation into a separate business unit (shared services centre) whose task is to provide and manage these services as value-adding activities. After the consolidation and concentration of these activities, the various processes can be standardised, optimised, and automated to promote efficiency, reduce costs, improve quality, and add value to the business units of the organisation. Shared services can be seen as an additional business unit that only provides support services at a fee to the business units. The services provided can be transactional or advisory. Some examples of transactional shared services include recruitment, payroll administration, medical aid administration, information technology support, and quality assurance support; while advisory shared services include advice on training programmes, choosing medical aid schemes, and interpreting a disciplinary code.

Ulrich [14] notes some of the characteristics of shared services:

- Shared services usually operate as a stand-alone unit, and in most cases are independent entities. They should be run as a business, and should be seen as an internal outsourcing partner.

- They can be geographically separate from headquarters, provided that they have adequate information and communication technology.

- Shared services are process-oriented, and focus on specific non-strategic and businesssupporting activities.

- They are driven by market competitiveness. The services are the organisation's 'product'. These services should be provided at a low cost through concentrated effort and economies of scale. Their relatively lower service costs and higher quality levels should make them a more attractive option, and they should be the first stop before an organisation seeks external providers.

- Shared services leverage technological investments, and because of their concentration, they can demand better prices and discounts. Shared services can justify the purchase of enabling technology. Typically a business unit will not afford leading-edge technology by itself. By pooling resources with other divisions, the cost of technology - such as enterprise resource software - can be justified.

- They focus on services and support given to business units, which goes beyond even the traditional notion of customer service or client support. The basis is the creation of an 
increased level of internal supplier-internal customer service relationships, raised to the level of partnerships.

- They help to create a flatter organisational structure - a step towards globalisation and outsourcing.

- They focus on continuous improvement.

The benefits of shared services are summarised as follows (Corporate Leadership Council Report [2]; Ulrich [14]; Redman et al. [9]; Schulman et al. [11]):

- Reduced administrative expenses and improved efficiency by capitalising on economies of scale, consolidation, standardisation, and automation of processes while improving service quality.

- More time is created for staff and senior management from the business units to focus their attention on strategic issues and the needs of their customers, because they do not have to spend time managing support services.

- A critical mass of services is created, justifying technological improvements and support service staff development. This critical mass also facilitates services engaging in strategic goals. For example, a human resources shared services centre can focus on improving services by concentrating on the strategic improvement of organisational performance.

- There is an accumulation of intellectual and capital assets within shared services, making a large number of affordable experts available to deal with complex issues.

- There is an opportunity to deploy new service-related technology, which can be afforded through cost-sharing by the multiple business units, thus reducing unit costs.

- It also allows the possibility of doing work more quickly and efficiently because experts and specialists engage in more focused work.

Hence, from the parent corporation's point of view, there should be reduced operating costs, improved quality of service to internal customers in particular, fewer distractions for the staff involved in core activities, and an opportunity to measure the shared services unit as another profit centre. From the perspective of the business units, there should be increased efficiencies through standardised processes, better quality of service received, increased internal customer satisfaction, decreased personnel requirements (because fewer employees are needed to produce the same result), and improved economies of scale through the concentration of specialised services. Savings will be made by eliminating duplication, streamlining processes, and re-engineering the workflow. Despite the benefits, Tham [13] cautions organisations not to implement shared services merely because they make economic sense and because other organisations are implementing them, but to implement them only if they enhance the achievement of business objectives.

Bergeron [1] suggests the following as the key success factors for shared services:

- Effective leadership. This requires senior managers with entrepreneurial spirit, a positive outlook, excellent communication skills, flexibility, tolerance for ambiguity, clarity of purpose, an ability to articulate a clear vision for the company, competence with analytical tools, and experience with change management.

- Effective workforce. The availability of highly skilled workers, a supportive business culture, a high level of employee morale, and open employee communications are necessary.

- Market opportunities. An attractive industry, and significant barriers to the entry of competitors, are important.

- Operational excellence. This involves regular performance monitoring and improvement through benchmarks and organisational structure.

- Superior technology. The best and most appropriate systems infrastructure is necessary to support the company's processes.

- Metrics. It is necessary to have a set of metrics to measure the benefits of shared services. People manage what they can measure and what they are measured against, and the company needs to know what to improve and how to measure whether or not 
improvement is taking place (Schulman et al. [11]). So appropriate metrics - such as costs, cycle time, productivity, and quality - are an essential ingredient of an effective and efficient shared services environment.

Schulman et al. [11] identify the various elements that are essential to a shared services environment to secure good relationships between the various business units and the shared services centre. These include service level agreements, very knowledgeable, skilled and experienced shared services employees, good two-way communication channels, a service centre (call centre/help desk), and a range of services that add value to the business units. These elements were further investigated and developed into a quality framework to enhance and improve services in a shared service environment (Ramphal [8]).

Despite the benefits and advantages mentioned above, many challenges are associated with the implementation of shared services, especially in South Africa. Kearney [5] indicates that poor leadership, lofty visions, poor scope, ineffective communication and training, and unstable technology are common challenges for shared services. An over-reliance on technology may not only be expensive in capital investment, but may also unconsciously lead to depersonalised services that might make internal customers uncomfortable. For example, human resources might eradicate the 'human touch' from its distinctive functions if it believes in being completely technology-driven (Reilly [10]). In addition, the lack of appropriate costing systems leads to much disparity and inequity in how chargeback is calculated (David [3]).

\section{RESEARCH METHODOLOGY}

The first part of the research design consisted of an intensive literature review on the topic of shared services. As this is relatively a new concept, there is very little academic research-based literature; the major sources are text books, case studies written by practitioners, and literature on outsourcing. In addition, a literature review in the area of quality was conducted to identify possible shared service quality dimensions. All of these sources are non-South African. A 90-minute focus group discussion with nine senior users of shared services was conducted to test and gather any additional parameters for the testing of the performance of shared services.

A questionnaire was used as the measuring tool. It had various sections relating to the organisational and personal details of the respondent, details of the business unit, details of the shared services units, and a performance evaluation of their shared services. The sections relating to the performance evaluation of shared services consisted of the following:

\subsection{Section 1}

Five questions relating to the performance of shared services were evaluated on a sevenpoint Likert scale. The respondents were asked to indicate their level of agreement with the lowering of operating costs, better time utilisation by staff, fair price paid for services, choice of using external service providers, and improvement of internal customer satisfaction by the introduction of shared services. Data analysis consisted of the calculation of the mean values.

\subsection{Section 2}

Six quality factors and 30 subfactors for the evaluation of quality in shared services were constructed from the literature reviews and the focus group. The factors were; shared service provision, shared service employees, service level agreements, service centre, communication, and shared service products. The respondent had to evaluate these criteria in terms of 'current status' and 'desired status'. This helped to identify the quality 'gaps'. Zeithaml, Berry \& Parasuraman [16] defined a 'quality gap' as the difference in customers' 
perceptions of 'current status' and 'desired status' of quality factors. Data was analysed and interpreted by the calculation of the means.

\subsection{Section 3}

This consisted of three questions to measure the overall feeling of the business unit manager by selecting an option for each question:

(a) the overall satisfaction level of shared services providers (not satisfied, marginally satisfied, satisfied, highly satisfied)

(b) the relationship of the business unit and shared services unit (no relationship, bad, good, excellent)

(c) business unit manager's comfortableness in not having direct control of support services (yes, no)

Percentage calculations were used to report these data.

Various steps were taken to ensure the validity of the results, including pre-testing the questionnaire by an expert on questionnaire design and two shared services consultants. The expert in questionnaire design is a senior lecturer and statistical services manager at a certain university. The shared services practitioners are post-graduate students in shared services, each with more than two years' experience in the field. In addition, the questionnaires were initially tested with five respondents, and minor corrections were made before conducting the research. The target respondents had to be business unit managers who had been shared services recipients for at least two years.

A judgement sample was chosen. This method is used when the researcher uses personal judgement to select a sample. Leedy \& Ormrod [6] describe judgement sampling as purposive sampling, implying that the sample is chosen for a particular purpose. Sekaran [12] explains that the members of such a sample are the best respondents to provide the researcher with the required information and expert knowledge. This method is useful when working with small samples and selecting those respondents who are knowledgeable about the subject under investigation. The questionnaire was emailed to potential respondents; 64 responses came back, of which only four were rejected. Of the 60 acceptable responses received, 16 completed only the section on 'desired' quality; so the quality gap was evaluated using the remaining 44 respondents who had completed both the 'desired' and the 'current' sections. The respondents were from ten major South African shared services organisations.

The data was collected over three months, with regular reminders being sent to the respondents. It was difficult to encourage the respondents to complete the questionnaires. Various respondents gave reasons over the telephone for not completing the questionnaires. The data collected was coded into an Excel spread sheet, and analysed with SPSS V 15.0 software.

\section{RESULTS}

\subsection{Profile of respondents}

The sample consisted of board members (4\%), executive members (26\%), senior managers (35\%) and middle managers (35\%), indicating a good spread of management. Of the sample, $42 \%$ managed an entire business unit, and $58 \%$ managed subsections of a business unit. They were aged between 28 and 58 years, had at least two years' experience of support from shared services, and had university qualifications. The respondents thus formed a mature group. 


\subsection{Profile of the business units}

All the sampled business units had been using shared services for more than two years. They were in the following economic sectors: research (14\%), support services (5\%), legal services $(2 \%)$, government services $(16 \%)$, energy $(25 \%)$, health $(11 \%)$, transport $(2 \%)$, manufacturing $(15 \%)$, and mining $(10 \%)$. This shows that the business units were representative of the South African economy, and that shared services were used in many economic sectors.

Two respondents indicated that they had business units in South Africa and in other parts of Africa, while one respondent indicated that their business units were in South Africa, in other parts of Africa, and in the UK, Europe, the USA, and India. The majority of the business units were South African organisations distributed over a number of provinces. The number of employees per business unit ranged from 100 to 4,000. Sixty percent of them generated turnover of more than R55 million, and $81 \%$ of them had been in business for more than five years.

\subsection{Profile of the shared services units}

The most common services provided to business units were human resources services, financial services, information technology, computer services, and procurement, and supply chain services. The literature indicates that in a mature shared services environment, the shared services unit does not have to be situated at head office or on any other companyrelated site. However, $41 \%$ of the shared services centres were located at the head office Of the respondents, $46 \%$ indicated that the shared services should be available during all the operating hours of the business unit; $21 \%$ indicated that they were necessary most of the time; and $23 \%$ said that they were sometimes necessary. A total of $12 \%$ indicated that they were not necessary; in other words, shared services should provide their services in the background and not operate during the same hours as the business unit. From these different responses, it appears that the preference is for shared services to be available during the business units' operating hours.

The literature shows that using shared services reduces the operating costs of business units, making more time available to their staff because they are no longer involved in support services; also the business unit receives better service, with higher levels of customer satisfaction. In addition, business units are expected to pay a fee for shared services, which is taken to be a fair price for the services rendered to them. Shared services and policies should provide for the outsourcing of functions if the internal services do not satisfy the business units.

\subsection{Results for Section 1 of the questionnaire}

The results of the five pertinent areas of shared services performance are shown in Table 1. Respondents evaluated each statement on a 7-point Likert scale.

\begin{tabular}{|l|l|l|}
\hline \multicolumn{2}{|l|}{$\mid \begin{array}{l}\text { There has been a reduction of the business unit's operating costs since the } \\
\text { introduction of shared services. }\end{array}$} & 3.84 \\
\hline 2 & $\begin{array}{l}\text { The staff of the business unit have more time for core activities because of } \\
\text { the introduction of shared services. }\end{array}$ & 3.64 \\
\hline 3 & The business unit pays a fair price for the shared services used. & 3.68 \\
\hline 4 & $\begin{array}{l}\text { The business unit would utilise services from external sources if they were } \\
\text { better than those provided by the shared services unit. }\end{array}$ & 3.64 \\
\hline 5 & $\begin{array}{l}\text { The customer satisfaction level of the business unit increased because of the } \\
\text { use of the shared services. }\end{array}$ & 3.00 \\
\hline
\end{tabular}

Table 1: Results of Section 1 


\begin{tabular}{|c|c|c|c|c|c|}
\hline Item no. & & $\begin{array}{c}\text { Mean } \\
\text { current }\end{array}$ & $\begin{array}{c}\text { Mean } \\
\text { Desired }\end{array}$ & $\begin{array}{c}\text { Diff } \\
\text { qual gap }\end{array}$ & 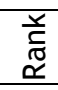 \\
\hline \multicolumn{2}{|c|}{ Factor 1: Service provision } & 3.65 & 5.76 & 2.11 & 1 \\
\hline 1 & $\begin{array}{l}\text { The shared services provision occurs with a } \\
\text { sense of urgency. }\end{array}$ & 3.50 & 6.00 & 2.50 & \\
\hline 2 & $\begin{array}{l}\text { The shared services providers notify } \\
\text { business units when there are changes in } \\
\text { the service plans that can affect business. }\end{array}$ & 4.11 & 6.00 & 1.89 & \\
\hline 3 & $\begin{array}{l}\text { The shared services are provided as } \\
\text { requested even if the request in } \\
\text { emergencies may be in conflict with the } \\
\text { objectives of the shared services unit. }\end{array}$ & 3.41 & 5.21 & 1.80 & \\
\hline 4 & $\begin{array}{l}\text { The shared services provision is continually } \\
\text { evaluated in terms of the quality of service } \\
\text { rendered to business units. }\end{array}$ & 4.18 & 5.84 & 1.66 & \\
\hline 5 & $\begin{array}{l}\text { The procedures and controls of shared } \\
\text { services provisioning are not bureaucratic. }\end{array}$ & 3.05 & 5.74 & 2.24 & \\
\hline \multicolumn{2}{|c|}{ Factor 2: Shared services employees } & 3.84 & 5.81 & 1.97 & 3 \\
\hline 6 & $\begin{array}{l}\text { The shared services employees are } \\
\text { available when needed by business units. }\end{array}$ & 4.07 & 6.02 & 1.95 & \\
\hline 7 & $\begin{array}{l}\text { The shared services employees are } \\
\text { specialists with the necessary expertise in } \\
\text { their respective functions. }\end{array}$ & 4.48 & 5.87 & 1.39 & \\
\hline 8 & $\begin{array}{l}\text { The shared services employees understand } \\
\text { the strategic operations of business units. }\end{array}$ & 3.80 & 5.74 & 1.94 & \\
\hline 9 & $\begin{array}{l}\text { The shared services employees are } \\
\text { proactive in dealing with the service needs } \\
\text { of business units by taking action without } \\
\text { the need for formal requests. }\end{array}$ & 3.18 & 5.86 & 2.68 & \\
\hline 10 & $\begin{array}{l}\text { The shared service employees are tolerant } \\
\text { towards the staff of the business units who } \\
\text { may make mistakes when making use of } \\
\text { shared services. }\end{array}$ & 3.68 & 5.55 & 1.87 & \\
\hline \multicolumn{2}{|c|}{ Factor 3: Contact centre } & 4.30 & 6.00 & 1.70 & 5 \\
\hline 11 & $\begin{array}{l}\text { The shared services helpdesk/call centre is } \\
\text { available during the entire operating hours } \\
\text { of the business unit. }\end{array}$ & 5.31 & 5.83 & 0.52 & \\
\hline 12 & $\begin{array}{l}\text { The shared services helpdesk/call centre } \\
\text { ensures that problems are addressed } \\
\text { without delay. }\end{array}$ & 4.00 & 6.23 & 2.23 & \\
\hline 13 & $\begin{array}{l}\text { The shared services helpdesk/call centre } \\
\text { agents provide assistance with problems } \\
\text { without unnecessarily referring them to } \\
\text { other parties. }\end{array}$ & 3.79 & 5.95 & 2.16 & \\
\hline 14 & $\begin{array}{l}\text { The shared services helpdesk/call centre } \\
\text { agents will refer requests that are not } \\
\text { completed in the allotted time. }\end{array}$ & 4.33 & 6.08 & 1.75 & \\
\hline 15 & $\begin{array}{l}\text { The shared services helpdesk/call centre } \\
\text { agents consult with the originators of the } \\
\text { requests before marking them as } \\
\text { completed. }\end{array}$ & 4.05 & 5.90 & 1.85 & \\
\hline
\end{tabular}




\begin{tabular}{|c|c|c|c|c|c|}
\hline \multicolumn{2}{|c|}{ Factor 4: Service level agreements } & 4.37 & 6.08 & 1.71 & 6 \\
\hline 16 & $\begin{array}{l}\text { The service level agreements are drawn up } \\
\text { jointly by the business units and the shared } \\
\text { services unit. }\end{array}$ & 4.56 & 6.02 & 1.46 & \\
\hline 17 & $\begin{array}{l}\text { The roles and responsibilities of business } \\
\text { units and the shared services provider are } \\
\text { clearly documented in the service level } \\
\text { agreement. }\end{array}$ & 4.78 & 6.22 & 1.44 & \\
\hline 18 & $\begin{array}{l}\text { The service level agreement shows a } \\
\text { detailed structure of the standards (e.g. } \\
\text { quality, cost and response) for service } \\
\text { delivery. }\end{array}$ & 4.66 & 6.10 & 1.44 & \\
\hline 19 & $\begin{array}{l}\text { The service level agreement includes a } \\
\text { procedure for the resolution of disputes. }\end{array}$ & 4.41 & 5.86 & 1.45 & \\
\hline 20 & $\begin{array}{l}\text { The shared services unit always provides } \\
\text { services as documented in the service level } \\
\text { agreement. }\end{array}$ & 3.41 & 6.19 & 2.78 & \\
\hline \multicolumn{2}{|c|}{ Factor 5: Communication } & 3.83 & 5.90 & 2.07 & 2 \\
\hline 21 & $\begin{array}{l}\text { The shared services unit keeps business } \\
\text { units informed of the progress of the } \\
\text { requests initiated. }\end{array}$ & 3.95 & 6.17 & 2.22 & \\
\hline 22 & $\begin{array}{l}\text { The shared services unit provides } \\
\text { communication channels to receive } \\
\text { feedback on their performance from the } \\
\text { business units. }\end{array}$ & 4.14 & 6.22 & 2.08 & \\
\hline 23 & $\begin{array}{l}\text { The shared services unit frequently } \\
\text { provides the business unit with shared } \\
\text { services performance reports. }\end{array}$ & 3.34 & 5.73 & 2.39 & \\
\hline 24 & $\begin{array}{l}\text { The shared services unit ensures that a } \\
\text { menu of their services and products is } \\
\text { communicated to the business units. }\end{array}$ & 3.52 & 5.95 & 2.43 & \\
\hline 25 & $\begin{array}{l}\text { The shared services unit utilises the most } \\
\text { efficient technology for service delivery. }\end{array}$ & 4.18 & 5.80 & 1.62 & \\
\hline 26 & $\begin{array}{l}\text { The shared services unit communicates } \\
\text { general information through newsletters, } \\
\text { intranet or other means of communication. }\end{array}$ & 3.84 & 5.53 & 1.69 & \\
\hline \multicolumn{2}{|c|}{ Factor 6: Shared services products } & 3.94 & 5.85 & 1.91 & 4 \\
\hline 27 & $\begin{array}{l}\text { The shared services unit promotes 'self- } \\
\text { service' products to its clients. }\end{array}$ & 3.86 & 5.50 & 1.64 & \\
\hline 28 & $\begin{array}{l}\text { The shared services unit provides services } \\
\text { that add value to the business unit. }\end{array}$ & 4.41 & 6.23 & 1.82 & \\
\hline 29 & $\begin{array}{l}\text { The shared services unit provides training } \\
\text { to the business unit employees in the use } \\
\text { of the services offered. }\end{array}$ & 3.77 & 5.82 & 2.05 & \\
\hline 30 & $\begin{array}{l}\text { The business unit is notified when there } \\
\text { are changes to the menu of services } \\
\text { offered. }\end{array}$ & 3.73 & 5.87 & 2.14 & \\
\hline
\end{tabular}

Table 2: The level of the 'current' and 'desired' quality, and the quality 'gap' 
All statements have a mean value of less than four, indicating that none of the statements appears to be at the top end of the scale. This means that for these South African shared services, the business unit managers have not seen a significant reduction in operating costs, the staff are not finding that they have more time for core activities, the business units do not believe that they are paying a fair price for services, the business units do not have much flexibility to outsource service functions (they may be forced to support the services from the shared service centre), and there are no significant increases in the level of internal customer satisfaction. This is a significant concern, and it justifies further research into the implementation of shared services structures. The reduction of operating costs and the level of customer satisfaction are linked to the quality of the service. The low results for these two statements show the need for improved quality in the delivery of services.

\subsection{Results for Section 2 of the questionnaire}

The results in Table 2 show the 'current' and 'desired' level of quality. The mean of the factor is the mean of the sub-factors using a 7-point Likert scale. In the doctoral study (Ramphal [8]), reliability analyses on the sub-factors, using Cronbach alpha as the measurement, were conducted to investigate the consistency of the results. The Cronbach alpha coefficients of all sub-factors were greater than 0.7 , indicating that the results were consistent. The quality 'gap' is the absolute difference between the 'current' and 'desired' means, and identifies those areas that are not performing to the expectations of the user. The major quality problems (in rank order) are: service provision (rank 1), communication (rank 2), shared service employees (rank 3), shared service products (rank 4), contact centre (rank 5), and service level agreements (rank 6). This shows that the quality of the shared service does not meet the expectations of the business unit managers.

\subsection{Results for Section 3 of the questionnaire}

The results show that only $23 \%$ of the business unit managers were satisfied with the quality of shared services received. This means that $77 \%$ of them were not really satisfied. In addition, a significant proportion (40\%) of business unit managers did not have an amicable relationship with the shared services managers. Despite these challenges, it appears that a larger proportion (55\%) was content with having only indirect control of services, which shows that there was a measure of confidence in using shared services.

\section{CONCLUSIONS AND FURTHER RESEARCH}

This article reports on some results that were incidental to a doctoral study on shared services involving ten South African organisations (Ramphal [8]). The extent to which the business unit managers were satisfied with the performance of shared services was also investigated.

The shared services methodology has been adopted and continues to be an attractive structure for South African organisations. The literature and case studies by international practitioners on shared services indicate that organisations using shared services show lower operating costs, improved efficiencies, and higher internal customer satisfaction. However, this study shows that the same cannot be said for South African organisations. Costs have not yet decreased, efficiencies have not improved, and internal customer satisfaction has not increased. Reasons for this poor performance (suggested by Kearney [5]) could be poor leadership, lofty visions, poor scope, ineffective communication and training, and unstable technology. There are also significant quality gaps in the provision of shared service. One suggestion is to enhance the quality of services in a shared service environment by means of the quality framework developed as the core of the author's larger study (Ramphal [8]). Perhaps this topic will be of interest to the industrial engineering community and other researchers who might diagnose this underperformance or validate this output with a much bigger sample. An interesting question is whether the shared services structures in South Africa are the same as those implemented in other 
countries; and perhaps seasoned South African shared services practitioners are best placed to answer it. It is also good to learn that, although business unit managers in general have under-rated the performance, they fully support the structure. Their support could go a long way to making the South African version of shared services the best in the world.

\section{REFERENCES}

[1] Bergeron, B. 2003. Essentials of shared services, Upper Saddle River, New Jersey: Wiley.

[2] Corporate Leadership Council Report. 2006. HR shared services: Determining the scope, scale and structure, Corporate Executive Board (catalogue no. CLC15GXNSI), pp. 1-9.

[3] David, I.T. 2005. Financial management shared services: A guide for federal users, Journal of Government Financial Management, 54(4), pp. 55-9.

[4] Grant, G., McKnight, S., Uruthirapathy, A. \& Brown, A. 2007. Designing governance for shared services organizations in the public service, Government Information Quarterly, 24(3), 522-539.

[5] Kearney, A.T. 2005. Shared services in government, http://www.akearney.com/ [accessed 28/5/09].

[6] Leedy, P.D. \& Ormrod, J.E. 2005. Practical research, planning and design, Englewood Cliffs, New Jersey: Pearson-Prentice Hall.

[7] Mercer. 2008. Finding your place on the HR continuum, http://www.mercer.com [accessed 28/05/09].

[8] Ramphal, R.R. 2010. A quality framework for services in a shared service environment, unpublished doctoral thesis, Tshwane University of Technology.

[9] Redman, T., Snap, E., Wass, J. \& Hamilton, P. 2007. Evaluating the human resources shared services model, International Journal of Human Resources Management, 18(8), pp. 1486-1506.

[10] Reilly, P. 2000. Making HR shared services work, Journal of European Industrial Training, 29(9), pp. 527-528.

[11] Schulman, D.S., Dunleavy, J.R., Harmer, M.J. \& Lusk, J.S. 1999. Shared services, adding value to business units. New York:Wiley.

[12] Sekaran, U. 2000. Research methods for business. New York: Wiley.

[13] Tham, I. 2005. Shared services: getting it right, Management Focus, February, pp. 13.

[14] Ulrich, D. 2006. Improving shared services implementation: Adopting lessons from BPR improvement, Business Process Management Journal, 12(2), pp. 191-205.

[15] Webster, D.W. 2007. Financial and shared services, Journal of Government Financial Management, 56(2), pp. 39-42.

[16] Zeithaml, V.A., Berry, L.L. \& Parasuraman, A. 1988. Communication and control processes in the delivery of service quality, Journal of Marketing, 52(2), pp. 35-48. 